\title{
Effect of Growth Regulators on Physiological Parameters of Strawberry (Fragaria $x$ ananassa Duch.) cv. Chandler
}

\author{
R. Swamy Sekhar ${ }^{1 *}$, Kuldeep Mehta ${ }^{2}$, S. Kundu ${ }^{1}$ and B. Ghosh ${ }^{1}$ \\ ${ }^{1}$ Department of Fruits and Orchard Management, Bidhan Chandra Krishi Viswavidyalaya, \\ Mohanpur, Nadia, West Bengal, India \\ ${ }^{2}$ Department of Fruit Science, Dr. Y. S. Parmar University of Horticulture and Forestry, \\ Nauni, Solan - 173230, India \\ *Corresponding author
}

\begin{abstract}
A B S T R A C T

\begin{tabular}{|l|}
\hline Ke y w or d s \\
Growth regulators, \\
Strawberry, \\
Chandler \\
\hline Article Info \\
\hline Accepted: \\
20 March 2018 \\
Available Online: \\
10 April 2018 \\
\hline \hline
\end{tabular}

The experiment was conducted at an elevation of $1250 \mathrm{~m}$ above mean sea level at $30^{\circ} 51^{\prime} \mathrm{N}$ latitude and $76^{\circ} 11^{\prime} \mathrm{E}$ longitude at the experimental area of the Department of Fruit Science, Dr. Yashwant Singh Parmar University of Horticulture and Forestry, Nauni, Solan (Himachal Pradesh). The aim of present investigation is to study the effect of different growth regulators on physiological parameters in Chandler cultivar of strawberry in terms of stomatal resistance, transpiration rate, leaf photosynthetic rate and chlorophyll content. The experiment was conducted in randomized block design with three replications and 19 treatments viz., Pro.Ca @ 30,60,90 ppm; CPPU @ 2, 4, 6 ppm, GA 3 @ 25, 50,75 ppm, Ethephon@50,100,150 ppm, NAA@ 20,30,60 ppm, CPPU + GA 3 2+50, $4+50,6+50 \mathrm{ppm}$ and control. The growth regulators applied to the plants twenty days before flowering. The growth regulators exhibited significant effect on the physiological characters in strawberry plants. The CPPU treatment followed by $\mathrm{GA}_{3}$ alone and combined treatment resulted in maximum chlorophyll content, rate of photosynthesis, stomatal conductance, transpiration rate and minimum stomatal resistance.
\end{abstract}

\section{Introduction}

Strawberry (Fragaria $x$ ananassa Duch.) is one of the most popular soft fruit, being delicate in flavour and rich in vitamins and minerals, is a valuable food in the diets of millions of people around the globe. Among the fruits, strawberry gives the quickest return in the shortest possible time. During the recent years, there has been a phenomenal increase in its area and production in northern Indians plains under subtropical climate (Sharma and
Sharma, 2004). Strawberry in these localities is planted in autumn and it comes to flowering in spring after about four months. In this short growing period, plants make only limited in vegetative growth, as a result, low yields are achieved (Arsey et al., 2004). Shan et al., (2007) reported that foliar application of IAA at $50 \mathrm{ppm}$ on strawberry cv. French improved the fruit quality in autumn and significantly increased the net photosynthesis and the content of chlorophyll a and b. Shan et al., (2007) studied the effect of different plant 
growth regulators on the photosynthesis and quality of strawberry cv. French. The result showed that 6-BA applied at $50 \mathrm{ppm}$ in late autumn significantly increased the net photosynthesis rate, the content of chlorophyll $\mathrm{a}$ and $\mathrm{b}$ and improved the quality. Application of $\mathrm{GA}_{3}$ significantly increased photosynthesis because of increased vegetative growth Ashraf et al., (2002) in wheat and Yuan and $\mathrm{Xu}$ (2001) in broad bean and soybean and Coulombe and Paquin (1959) in Tomato.

\section{Materials and Methods}

The present investigation was carried out in the experiment area of Department of Fruit Science, University of Horticulture and Forestry, Nauni, Solan, H. P. India. Thirty two healthy runners were planted in $2 \times 2 \mathrm{~m}$ raised bed at a distance of $50 \times 25 \mathrm{~cm}$.

The whole experiment was conducted in randomized block design with three replications. A single spray of growth regulators were applied to the plants twenty days before flowering. The treatments of growth regulators were applied as follows :

$\mathrm{T}_{1}$ - Pro.Ca@ 30 ppm, $\mathrm{T}_{2}$ - Pro.Ca @60 ppm, $\mathrm{T}_{3}$ - Pro.Ca@90 ppm, T4- CPPU @ 2 ppm, $\mathrm{T}_{5}$ - CPPU @ 4 ppm, $\mathrm{T}_{6}-\mathrm{CPPU} @ 6 \mathrm{ppm}, \mathrm{T}_{7}$ - $\mathrm{GA}_{3} @ 25$ ppm, T8 - GA 3050 ppm, T9 $\mathrm{GA}_{3} @ 75$ ppm, $\mathrm{T}_{10}$ - Ethephon@50 ppm, $\mathrm{T}_{11}$-Ethephon@100 ppm, $\mathrm{T}_{12}$ - Ethephon@ 150 ppm, T13- NAA @ 20 ppm, T14- NAA @ 30 ppm, $\mathrm{T}_{15}$ - NAA @ 60 ppm, $\mathrm{T}_{16}-\mathrm{CPPU}+$ $\mathrm{GA}_{3} @ 2+50 \mathrm{ppm}, \mathrm{T}_{17}-\mathrm{CPPU}+\mathrm{GA}_{3} @ 4+50$ ppm, $\mathrm{T}_{18}-\mathrm{CPPU}+\mathrm{GA}_{3} @ 6+50$ ppm and $\mathrm{T}_{19}$ - control. Observations on various growth and fruiting characters were recorded by using standard method.

\section{Chlorophyll content}

Five fully expanded and mature leaves from each treatment were collected in the month of
July during morning hours (Halfacre et al., 1968) and immediately placed in ice box and brought to the laboratory. The samples were then kept in refrigerator at sub-zero degree temperature to avoid degradation of chlorophyll pigment.

The leaves under each sample were then chopped into fine pieces under subdued light and $100 \mathrm{mg}$ of chopped leaf samples were placed in vials containing $7 \mathrm{ml}$ of Dimethyl Sulphoxide. The contents of the vials were incubated at $65^{\circ} \mathrm{C}$ for half an hour and then, the extract was transferred to graduated test tube and the final volume was made to $10 \mathrm{ml}$ with Dimethyl sulphoxide (Hiscox and Israelstam, 1979).

\section{Estimation}

The optical density (O.D.) values of the extracts were recorded in spectrophotometer (Spectronic-20) at 645 and $663 \mathrm{~nm}$ wavelengths against a dimethyl sulphoxide blank. The total chlorophyll content was calculated by using the following formula:

$20.2 \mathrm{~A}_{645}+8.02 \mathrm{~A}_{663}$
Total chlorophyll content $=$
a x $1000 \times \mathrm{x} \mathrm{W}$

Where,

$\mathrm{V}=$ Volume of the extract made

$\mathrm{a}=$ Length of the light path in cell (usually $1 \mathrm{~cm})$

$\mathrm{W}=$ weight of the sample

$\mathrm{A}_{645}=$ Absorbance at $645 \mathrm{~nm}$

$\mathrm{A}_{663}=$ Absorbance at $663 \mathrm{~nm}$

The results obtained were expressed as mg of total chlorophyll per gram of fresh weight. 
Photosynthesis, stomatal conductance, resistance and transpiration

Photosynthesis, stomatal resistance, conductance and transpiration were recorded during fruit development stage. The observations were recorded between 9:00 to 12:00 am with the help of LICOR-6200 portable photosynthesis meter. The results were expressed in $\mu \mathrm{mol} / \mathrm{m}^{2} / \mathrm{s}, \mathrm{S} \mathrm{cm}^{-1}, \mathrm{~m} \mathrm{~mol} / \mathrm{s}$ and $\mathrm{m} \mathrm{mol} / \mathrm{m}^{2} / \mathrm{s}$ for photosynthesis, stomatal conductance, resistance and transpiration respectively (Fig. 1).

Data were subjected to statistical analysis in accordance with the method described by Gomez and Gomez (1984).

\section{Results and Discussion}

\section{Physiological parameters}

The growth regulators registered significant increase in the leaf chlorophyll content, photosynthesis, stomatal conductance, resistance and transpiration of strawberry $\mathrm{cv}$. Chandler (Table 1 and 2) the maximum chlorophyll content (3.729), photosynthesis (8.31) stomatal conductance (0.311) and transpiration (27.930) were recorded in $\mathrm{T}_{15}$ as compared to control $\left(\mathrm{T}_{19}\right)$.

It is clear from the present investigation that the leaf photosynthesis was significantly influenced with the application of various growth regulator treatments. The maximum photosynthesis was recorded with CPPU 6 $\mathrm{ppm}+\mathrm{GA}_{3} 50 \mathrm{ppm}$ (Table 1). These finding are in conformation with the work of Shan et al., (2007) in strawberry cv. French.

The increase in photosynthesis may be due to increased chlorophyll content (Winger et al., 1998). Application of $\mathrm{GA}_{3}$ significantly increased photosynthesis because of increased vegetative growth (Table 1). The present results are in conformity with those of Ashraf et al., (2002) in wheat and Yuan and Xu (2001) in broad bean and soybean and Coulombe and Paquin (1959) in Tomato.

Fig.1 LI-COR 6200 portable photosynthesis system

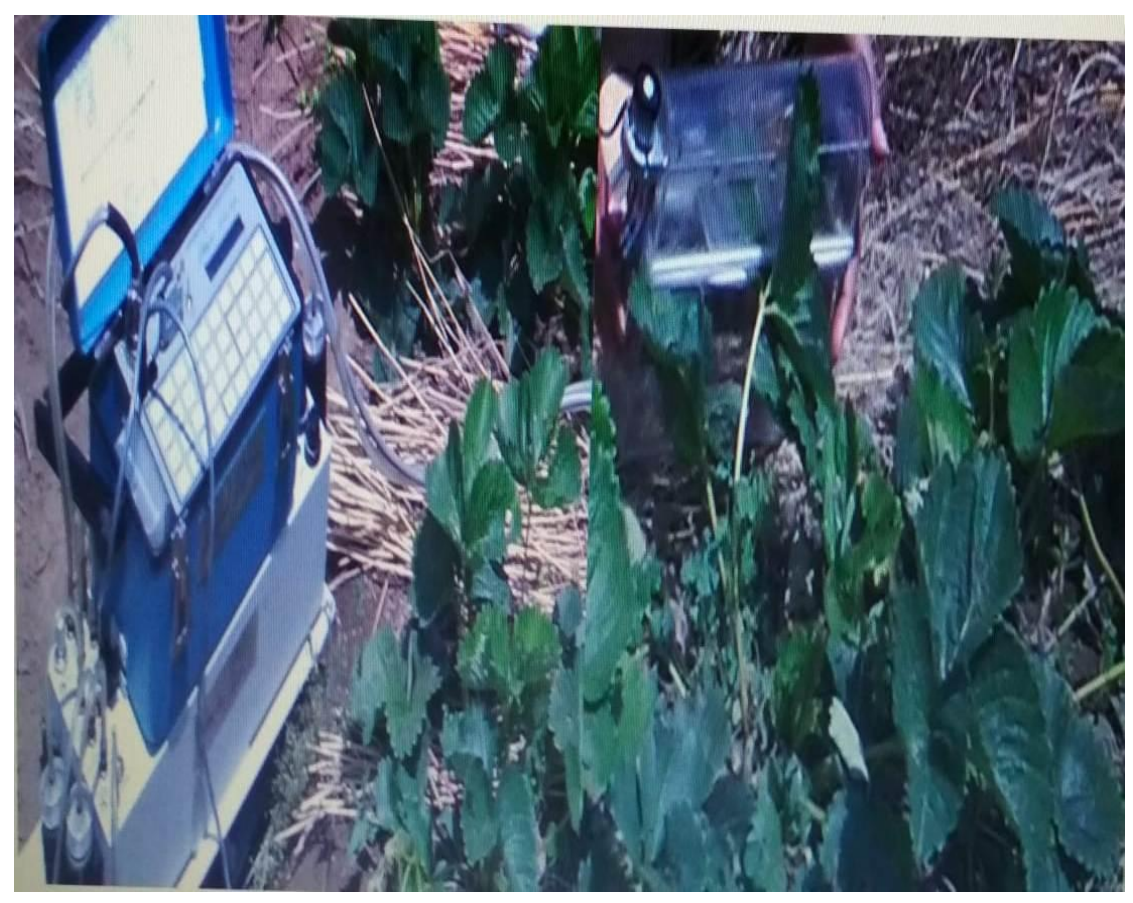


Table.1 Effect of different growth regulators on chlorophyll content and photosynthesis

\begin{tabular}{|c|c|c|c|c|c|c|}
\hline \multirow[t]{2}{*}{ Treatment } & \multicolumn{3}{|c|}{ Chlorophyll content (mg/g) } & \multicolumn{3}{|c|}{ Photosynthesis (micro mole/ $\mathrm{m}^{2} / \mathrm{sec}$.) } \\
\hline & 2011-12 & 2012-13 & Pooled & 2011-12 & 2012-13 & Pooled \\
\hline $\mathrm{T}_{1}$ Pro. Ca 30 ppm & 2.632 & 2.641 & 2.637 & 5.26 & 4.44 & 4.85 \\
\hline $\mathrm{T}_{2}$ Pro. Ca 60 ppm & 2.648 & 2.654 & 2.651 & 4.78 & 5.25 & 5.02 \\
\hline $\mathrm{T}_{3}$ Pro. Ca 90 ppm & 2.872 & 2.851 & 2.862 & 7.65 & 7.04 & 7.35 \\
\hline $\mathrm{T}_{4}$ CPPU 2 ppm & 3.298 & 3.372 & 3.336 & 5.1 & 6.26 & 5.68 \\
\hline $\mathrm{T}_{5}$ CPPU 4 ppm & 3.631 & 3.582 & 3.607 & 6.74 & 6.82 & 6.78 \\
\hline $\mathrm{T}_{6}$ CPPU 6 ppm & 3.695 & 3.596 & 3.646 & 7.39 & 7.37 & 7.38 \\
\hline $\mathrm{T}_{7} \mathbf{G A}_{3} 25 \mathrm{ppm}$ & 3.160 & 3.148 & 3.154 & 7.59 & 6.18 & 6.89 \\
\hline $\mathrm{T}_{8} \mathrm{GA}_{3} 50 \mathrm{ppm}$ & 3.168 & 3.184 & 3.176 & 7.62 & 6.69 & 7.16 \\
\hline $\mathrm{T}_{9} \mathrm{GA}_{3} 75 \mathrm{ppm}$ & 3.201 & 3.217 & 3.209 & 8.32 & 7.49 & 7.91 \\
\hline $\mathrm{T}_{10}$ Ethephon $50 \mathrm{ppm}$ & 2.591 & 2.584 & 2.588 & 4.33 & 4.76 & 4.55 \\
\hline$T_{11}$ Ethephon 100 ppm & 2.674 & 2.684 & 2.679 & 6.45 & 5.46 & 5.96 \\
\hline$T_{12}$ Ethephon $150 \mathrm{ppm}$ & 2.685 & 2.692 & 2.688 & 6.57 & 5.59 & 6.08 \\
\hline T $_{13}$ NAA $20 \mathrm{ppm}$ & 2.324 & 2.352 & 2.338 & 5.66 & 5.19 & 5.43 \\
\hline $\mathrm{T}_{14}$ NAA $30 \mathrm{ppm}$ & 2.436 & 2.395 & 2.416 & 5.46 & 5.62 & 5.54 \\
\hline T $_{15}$ NAA 60 ppm & 2.458 & 2.424 & 2.442 & 6.67 & 6.20 & 6.44 \\
\hline $\mathrm{T}_{16}$ CPPU $2 \mathrm{ppm}+\mathrm{GA}_{3} 50 \mathrm{ppm}$ & 3.524 & 3.518 & 3.521 & 7.81 & 7.69 & 7.75 \\
\hline $\mathrm{T}_{17}$ CPPU $4 \mathrm{ppm}+\mathrm{GA}_{3} 50 \mathrm{ppm}$ & 3.524 & 3.572 & 3.548 & 7.90 & 8.19 & 8.05 \\
\hline $\mathrm{T}_{18}$ CPPU $6 \mathrm{ppm}+\mathrm{GA}_{3} 50 \mathrm{ppm}$ & 3.682 & 3.775 & 3.729 & 8.24 & 8.37 & 8.31 \\
\hline $\mathrm{T}_{19}$ Control & 2.287 & 2.296 & 2.291 & 3.37 & 3.41 & 3.39 \\
\hline $\mathrm{CD}_{0.05}$ & 0.048 & 0.063 & 0.045 & 1.19 & 0.85 & 0.70 \\
\hline
\end{tabular}

Table.2 Effect of different growth regulators on stomatal conductance, resistance and transpiration

Treatment
$\mathrm{T}_{1}$ Pro. Ca $30 \mathrm{ppm}$
$\mathrm{T}_{2}$ Pro. Ca $60 \mathrm{ppm}$
$\mathrm{T}_{3}$ Pro. Ca $90 \mathrm{ppm}$
$\mathrm{T}_{4}$ CPPU $2 \mathrm{pmm}$
$\mathrm{T}_{5}$ CPPU $4 \mathrm{ppm}$
$\mathrm{T}_{6}$ CPPU $6 \mathrm{ppm}$
$\mathrm{T}_{7} \mathrm{GA}_{3} 25 \mathrm{ppm}$
$\mathrm{T}_{8}$ GA $50 \mathrm{ppm}$
$\mathrm{T}_{9}$ GA $75 \mathrm{ppm}$
$\mathrm{T}_{10}$ Ethephon $50 \mathrm{ppm}$
$\mathrm{T}_{11}$ Ethephon $100 \mathrm{ppm}$
$\mathrm{T}_{12}$ Ethephon $150 \mathrm{ppm}$
$\mathrm{T}_{13}$ NAA $20 \mathrm{ppm}$
$\mathrm{T}_{14} \mathrm{NAA} 30 \mathrm{ppm}$
$\mathrm{T}_{15} \mathrm{NAA} 60 \mathrm{ppm}$
$\mathrm{T}_{16}$ CPPU $2 \mathrm{ppm}+\mathrm{GA}_{3} 50 \mathrm{ppm}$
$\mathrm{T}_{17}$ CPPU $4 \mathrm{ppm}+\mathrm{GA}_{3} 50 \mathrm{ppm}$
$\mathrm{T}_{18}$ CPPU $6 \mathrm{ppm}+\mathrm{GA}_{3} 50 \mathrm{ppm}$
$\mathrm{T}_{19}$ Control
CD 0.05

Stomatal conductance ( $\mathrm{m} \mathrm{mol} / \mathrm{s}$ )

\begin{tabular}{|c|c|c|}
\hline $\mathbf{2 0 1 1 - 1 2}$ & $\mathbf{2 0 1 2 - 1 3}$ \\
\hline 0.407 & 0.399 \\
\hline 0.448 & 0.369 \\
\hline 0.422 & 0.412 \\
\hline 0.569 & 0.547 \\
\hline 0.547 & 0.572 \\
\hline 0.679 & 0.645 \\
\hline 0.547 & 0.525 \\
\hline 0.552 & 0.526 \\
\hline 0.527 & 0.587 \\
\hline 0.376 & 0.418 \\
\hline 0.443 & 0.351 \\
\hline 0.418 & 0.390 \\
\hline 0.415 & 0.431 \\
\hline 0.447 & 0.429 \\
\hline 0.445 & 0.433 \\
\hline 0.531 & 0.585 \\
\hline 0.565 & 0.603 \\
\hline 0.702 & 0.760 \\
\hline 0.326 & 0.296 \\
\hline 0.132 & 0.130 \\
\hline
\end{tabular}

Pooled

0.403

$$
0.408
$$
0.417 0.558 0.560 0.662 0.536 0.539 0.557 0.397 0.404 0.423 0.438 0.439 0.558 0.584 0.731 0.311 0.126
Stomatal resistance ( $\left(\mathrm{cm}^{-1}\right)$ 0.397

\section{1-12 2012-13 $\mid$ Pooled} \begin{tabular}{|l|l|l|}
\hline 0.720 & 0.762 \\
\hline
\end{tabular} \begin{tabular}{l|l}
0.572 & 0.994 \\
\hline 0.843 & 0.788
\end{tabular} 0.843

\subsection{0}

0.664

0.569

0.643

$$
0.683
$$

\subsection{6}

$$
0.904
$$

\subsection{3}

\subsection{4}

0.855

0.867

0.514

0.488

0.586

0.926

0.146

\begin{tabular}{l|l}
\hline 0.762 & 0.741 \\
\hline 0.788 & 0.783 \\
\hline
\end{tabular}

\begin{tabular}{|l|l|}
0.788 & 0.815 \\
\hline
\end{tabular}

\begin{tabular}{|l|l|}
\hline 0.717 & 0.688 \\
\hline
\end{tabular}

\begin{tabular}{|l|l|}
\hline 0.776 & 0.720 \\
\hline
\end{tabular}

\begin{tabular}{|l|l|}
0.764 & 0.738 \\
\hline
\end{tabular}

\begin{tabular}{l|l}
0.7696 & 0.582 \\
\hline
\end{tabular}

\begin{tabular}{l|l}
0.652 & 0.647
\end{tabular}

\begin{tabular}{|l|l|}
\hline 0.671 & 0.677 \\
\hline
\end{tabular}

\begin{tabular}{l|l}
0.6714 & 0.915 \\
\hline
\end{tabular}

\begin{tabular}{|l|l|}
\hline 0.973 & 0.938 \\
\hline
\end{tabular}

\begin{tabular}{|l|l|}
\hline 0.887 & 0.865 \\
\hline
\end{tabular}

\begin{tabular}{l|l}
0.785 & 0.824
\end{tabular}

\begin{tabular}{l|l}
0.885 & 0.870 \\
\hline
\end{tabular}

\begin{tabular}{|l|l|}
\hline 0.901 & 0.884 \\
\hline
\end{tabular}

\begin{tabular}{l|l}
0.547 & 0.530
\end{tabular}

\begin{tabular}{|l|l|}
\hline 0.547 & 0.530 \\
\hline 0.632 & 0.560
\end{tabular}

\begin{tabular}{l|l}
0.600 & 0.593
\end{tabular}

0.842

0.140

0.884

Transpiration rate $\left(\mathrm{m} \mathrm{mol} / \mathrm{m}^{2} / \mathrm{s}\right)$

\begin{tabular}{|c|c|c|}
\hline $\mathbf{2 0 1 1 - 1 2}$ & $\mathbf{2 0 1 2}-13$ & Pooled \\
\hline 20.02 & 19.34 & 19.680 \\
\hline 20.67 & 20.64 & 20.637 \\
\hline 21.35 & 20.31 & 20.830 \\
\hline 25.51 & 23.09 & 24.300 \\
\hline 23.64 & 24.76 & 24.200 \\
\hline 23.65 & 23.62 & 24.633 \\
\hline 22.47 & 20.76 & 21.613 \\
\hline 21.01 & 20.68 & 21.930 \\
\hline 24.12 & 24.26 & 24.190 \\
\hline 15.77 & 15.16 & 15.463 \\
\hline 16.66 & 16.29 & 16.473 \\
\hline 18.07 & 16.36 & 17.563 \\
\hline 17.92 & 19.18 & 18.450 \\
\hline 19.29 & 20.06 & 19.673 \\
\hline 20.93 & 18.94 & 19.937 \\
\hline 25.14 & 25.04 & 26.090 \\
\hline 25.06 & 25.65 & 26.853 \\
\hline 27.07 & 28.79 & 27.930 \\
\hline 15.15 & 14.62 & 14.383 \\
\hline 1.310 & 1.285 & 1.263 \\
\hline
\end{tabular}


In the present investigation, the increased photosynthesis was observed with Pro.Ca treatments. This finding is in accordance with the results of Sabatini et al., (2003) whose results exhibited higher net photosynthesis and 50 per cent increase in $\mathrm{CO}_{2}$ uptake when treated with Pro.Ca in apple. In low specific leaf area (SLA) of leaves, with the higher density of chlorophyll and photosynthetic enzymes increased the leaf net photosynthesis (Evans and Poorter, 2001). This investigation also shows that all concentrations of NAA increased net photosynthesis compared to control. This finding are in line with those of Shan et al., (2007) and Bidwell and Wendy (1966) who reported similar increase in photosynthesis rate with NAA application in strawberry cv. French and in beans, respectively. Similarly, Shun (2000) observed the effect of $\mathrm{CO}_{2}$ enrichment on application of NAA, GA and CPPU on photosynthesis in strawberry and found that their application were significantly effective in increasing net photosynthetic rate, with close correlations between net photosynthetic rate and intracellular $\mathrm{CO}_{2}$, stomatal conductance and transpiration rate, respectively. The application of $\mathrm{GA}_{3}$ at $150 \mathrm{ppm}$ also resulted in significantly higher rate of photosynthesis, stomatal conductance, transpiration rate in rice cultivars 'MR 219' and 'Pokkali' compared to those cultivars with no $\mathrm{GA}_{3}$ application (Misratia et al., 2013).

\section{Chlorophyll content}

The results of present investigation revealed that the growth regulators significantly increased the chlorophyll content (Table 1) and were the highest chlorophyll content was observed with CPPU @6 ppm+. GA 3 @50 ppm followed by CPPU @6 ppm and CPPU @ 4 ppm, respectively. The higher chlorophyll content may be due to greater synthesis and translocation of assimilates and water by cytokinins (CPPU) and gibberellins, which checks the degradation of chlorophyll in leaves (Reis et al., 1977). It may be due to some kind of anti-senescence property of these growth regulators. In the present study the application of Pro.Ca increased the leaf chlorophyll content. Similar increase in the chlorophyll per unit leaf area in apple leaves was also reported by Sabatini et al., (2003).

\section{References}

Ashraf, M., Karim, F. and Rasul, E. 2002. Interactive effects of gibberellic acid and salt stress on growth, ion accumulation and photosynthetic capacity of two spring wheat cultivars differing in salt tolerance. Plant Growth Regulation 36: 49-59.

Coulombe, L. J., and Paquin, R. 1959. Effect de Pacide giggerllique sur le metabolism des plantes. Canadian Journal of Botany 37: 897-901.

De Veau, E. J., Robinson, J. M., Warmbrodt, R. D. and Van Berkum, P. 1990. Photosynthesis and photosynthate partitioning in N2- fixing soybeans. Plant Physiol. 94: 259-267.

El Nagger, A. H., El Nagger, A. A. M. and Ismaiel, Naglaa, M. 2009. Effect of phosphorus application and gibberellic acid (GA3) on the growth and flower quality of Dianthus caryophyllus L. American Eurasian J. Agric. \& Environ. Scie. 6(4): 400-410.

Gomez, K., A. and Gomez, A., A. 1984. Statistical Procedure for Agricultural Research $\left(2^{\text {nd }}\right.$ ed.), John Willey and Sons Inc, New York, 680p.

Halfacre, R, G., Baradent, J., A. and Pollens, J. H. A. 1968. Effect of alar on morphology, chlorophyll contents and net $\mathrm{CO}_{2}$ assimilation rate of young apple trees. Proceedings of the American Society for Horticultural Science 193: 40-52.

Hiscox, J., D. and Israelstam, G. F. 1979. A method for the extraction of chlorophyll from leaf tissue without maceration. Canadian Journal of Botany 57: 13321334.

Kazemi, Mohsen. 2014b. Effect of gibberellic acid and potassium nitrate spray on vegetative growth and reproductive characteristics of tomato. J. Biol. Environ. Science 8(22): 1-9. 
Khan, N., A, Ansari, H., R and Samiullah. 1998. Effect of gibberellic acid spray during ontogeny of mustard on growth, nutrient uptake and yield characteristics. J. Agron. Crop Sci. 181: 61-63.

Lim, P. O., Woo, H. R. and Nam, H. G. 2003. Molecular genetics of leaf senescence in Arabidopsis. Trends in Plant Sci. 6: 272278.

Misratia, Khadija, M., Ismail, Mohd, Razi, Hakim, Md, Abdul, Mohamed, Hanafi, Musa and Puteh, Adam. 2013. Effect of salinity and alleviating role of gibberellic acid $\left(\mathrm{GA}_{3}\right)$ for improving the morphological, physiological and yield traits of rice varieties. Australian Journal of Crop Science 7(11):1682-1692.

Misratia, Khadija, M., Ismail, Mohd, Razi, Hakim, Md, Abdul, Mohamed, Hanafi, Musa, and Puteh, Adam. 2013. Effect of salinity and alleviating role of gibberellic acid $\left(\mathrm{GA}_{3}\right)$ for improving the morphological, physiological and yield traits of rice varieties. Australian Journal of Crop Science 7(11):1682-1692.

Resis, S. K., Wert, V. and Sweeley, C. C. 1977. Triacontanol- a new naturally occurring growth regulator. Science 195: 13391341.

Sabatini, E., Noferini, M., Fiori, G., Corelli, G. L. and Costa, G. 2003. Prohexadione-Ca positively affects gas exchanges and chlorophyll content of apple and pear trees. European Journal of Horticultural Science 68: 123-128.

Shahin, M. F., Fawzi, M. I. F. and Kandil, E. A. 2010. Influence of foliar application of some nutrient (Fertifol Misr) and gibberellic acid on fruit set, yield, fruit quality and leaf composition of 'Anna' apple trees grown in sandy soil. Journal of American Science 6(12): 202- 208.

Shan, S., Liu, G., Li, S and Miao, P. 2007. Effect of IAA, $\mathrm{GA}_{3}$ and 6-BA applied in autumn on plant quality of strawberry. Journal of Fruit Science 24 (4): 545-548.

Shun, Du, Yao. 2000. Effect of $\mathrm{CO}_{2}$ enrichment, and fruit application of NAA, GA and CPPU on photosynthesis of strawberry. Acta Agriculturae Zhejiangensis 12(3): 144-146.

Singh, Akath., and Singh, J. N. 2009. Effect of biofertilizers and bioregulators on growth, yield and nutrient status of strawberry cv. Sweet Charlie. Indian Journal of Horticulture 66(2): 220-224.

Turkyilmaz, Bengu. 2012. Effects of salicylic and gibberellic acids on wheat (Triticum aestivum L.) under salinity stress. Bangladesh J. Bot. 41(1): 29-34.

Wingler, A., Von, Schaewen, A., Leegood, R, C., Lea, P.J. and Quick, W. P. 1998. Regulation of leaf senescence by cytokinnin, sugars and light. Effect on $\mathrm{NADH}$ dependent hydroxypyruvate reductase. Plant Physiology 116: 329335.

Yuan, L. and Xu, D. Q. 2001. Stimulation effect of gibberellic acid short-term treatment on the photosynthesis related to the increase in Rubisco content in broad bean and soybean. Photosyn. Res. 68: 39-47.

\section{How to cite this article:}

Swamy Sekhar, R., Kuldeep Mehta, S. Kundu and Ghosh, B. 2018. Effect of Growth Regulators on Physiological Parameters of Strawberry (Fragaria $x$ ananassa Duch.) cv. Chandler. Int.J.Curr.Microbiol.App.Sci. 7(04): 2423-2428. doi: https://doi.org/10.20546/ijcmas.2018.704.278 